\title{
EFFICIENCY OF RHIZOHUMIN AND POLYMYXOBACTERIN APPLICATION IN COMBINATION WITH MICROFERTILIZER AND GROWTH REGULATOR ON LEAFLESS PEA CROPS IN NORTH STEPPE
}

Ishchenko V. A.

Kirovohrad State Agricultural Experimental Station

Institute of Agriculture of Steppe Zone NAAS,

2, Central Str., Sozonivka, Kirovohrad region, 27602

E-mail: cnz@kw.ukrtel.net

The paper presents trial results on application of microbial preparations of Ryzohumin and Polymyxobacterin in combination with plant growth regulator Emistim $C$ and microfertilizer Reakom on leafless peas crops in Northern Steppe region. Use of biological preparations have promoted increase of pea plants on $0.27-0.38 \mathrm{t} / \mathrm{ha}$ or 12.8 - 18.1\%, microfertilizer Reakom - on $0.36 \mathrm{t} /$ ha or $15.5 \%$, Emistim C - on $0.39-0.41 \mathrm{t} /$ ha or $16.8-17.7 \%$, and at their combined use - on $0.22-0.55 t /$ ha or $9.5-23.7 \%$.

Keywords: pea, growing technology, biological preparations, growth regulator, microfertilizer, yield, protein, economic and energy efficiency.

The introduction of intensive crop varieties with high genetic potential in agriculture requires formation in soils of plants' root zone a significant amount of available nutrients [1]. Increase of crop yields at this is primarily associated with improved nitrogen nutrition of plants [2]. Leguminous plants capable of forming nitrogen-fixing symbiosis with nodule bacteria play an important role in renewal and preservation of nitrogen in soils [3] while phosphorous is another limiting element in formation of crop yield. Due to the limited applicability of phosphate fertilizers in crop production, the importance of phosphorus supply for cultured plants is growing. Application of biological preparations in this view is an efficient way to enhance accumulation of atmosphere nitrogen in agrocenosis soils and improve phosphorus nutrition of plants $[4,5]$.

Thus, our research was aimed to study the efficiency of presowing seeds bacterization with microbial preparations separately and in combination with plant growth regulator and micronutrients.

Materials and methods. The influence of biological products, micronutrients and physiologically active substances on leafless pea plants (Tsarevich variety) was studied in Kirovohrad Institute of Agriculture NAAS (nowadays - Kirovohrad State Agricultural Experimental Station of the Institute of Agriculture of Steppe Zone NAAS).

Experiment variants have included seed treatment and spraying with microfertilizers and growth regulator (factor A): 1. Without treatment (control), 2. Reacom-C beans (4 1/ g), 3. Reacom-P beans (4 1/ ha) 4. Emistim C (10 ml / g), 5. Emistim C (10 ml / ha $), 6$. Reacom-C beans $(4 \mathrm{l} / \mathrm{g})+$ Emistim C $(10 \mathrm{ml} /$ ton $)$, 7. Emistim C $(10 \mathrm{~mL} / \mathrm{t})+$ Reacom-P beans (4 l / ha), 8. Reacom-C beans $(4 \mathrm{ml} / \mathrm{t})+$ Emistim C $(10 \mathrm{ml} / \mathrm{ha}) 9$. Reacom-P beans (4 l / ha $)+$ Emistim C (10 ml/ ha) and presowing seeds bacterization with biological preparations (factor B): 1. Without seeds bacterization (control), 2. Seeds treatment with Rhizohumin, $200 \mathrm{~g}$ per 1 ha of seeding rate, 3. Seeds treatment with Polymyxobacterin, $150 \mathrm{ml}$ of 1 ha of seeding rate. 
Seeds were inoculated on the seeding day in accordance to the recommendations [6] with microbial preparations based on pea rhizobia - Rhizohumin (TU U 24.1-00497360003:2007) and Polymyxobacterin (PMBC) which biological agent is phosphorous mobilizing bacterium Paenibacillus polymyxa KB (TU U 24.1-00497360-004:2009).

Micronutrient Reacom is a liquid composition of micronutrient formulation designed for pre-sowing treatment of seeds and legumes in the budding stage. This product has the following characteristics: $\mathrm{pH} 8.2$, density $-1.255 \mathrm{~g} / \mathrm{cm}^{3}$, zinc $(\mathrm{Zn})-20 \mathrm{~g} / 1$, copper $(\mathrm{Cu})-25$, boron $(\mathrm{B})-4.5$, molybdenum $(\mathrm{Mo})-1.0$ and cobalt $(\mathrm{Co})-0.04 \mathrm{~g} / 1$.

Plant growth regulators (PGR) Emistim $\mathrm{C}$ - product of biotechnological cultivation of micromycetes - epiphytes from ginseng roots. It has set of biologically active substances: amino acids, fatty acids, polysaccharides, organic acids and microelements.

Treatment of pea seeds with micronutrient preparation and PGR was performed 10 days prior to bacterization. Plants were sprayed at early budding stage. Farming techniques, besides with the exception of studied issues were common for the area. Record and monitoring were performed according to conventional and special techniques $[7,8]$.

Trials were conducted on plain medium-humic deep loamy black soils. The humus content in the plow layer of soil was $4.63 \%$ easily hydrolyzed nitrogen $-12 \mathrm{mg}$ per $100 \mathrm{~g}$ of soil, movable phosphorus and potassium - 11.6 and $11.8 \mathrm{mg}$ per $100 \mathrm{~g}$ soil, respectively; $\mathrm{pH}$ salt - 5.4. Climate - temperate continental, with average annual temperature $-8,0^{\circ} \mathrm{C}$, amount of rainfall $-499 \mathrm{~mm}$, most of which falling between April and October $-322 \mathrm{~mm}$. Hydrothermal coefficient by G.T. Selyaninov for peas growing season in 2009 was $0.4,2010-0.6$, thus indicating the lack of moisture for plants.

Results and discussion. Seeds treatment with Ryzohumin and PMBC had significantly increase crop yield - in average per variant on $0.36-0.44 \mathrm{t} /$ ha or $15.2-$ $19.5 \%$ at control values of $2.36 \mathrm{t} / \mathrm{ha}$. Reacom application had also enhanced yield of peas - on $0.36 \mathrm{t} / \mathrm{ha}$, or $15.5 \%$, growth regulator Emistim C $-0.39-0.41 \mathrm{t} /$ ha or $16.8-17.7 \%$ while their combination - on $0.22-0.55 \mathrm{t} /$ ha or $9.5-23.7 \%$. In variants without treatment (control) the yield was $2.32 \mathrm{t} / \mathrm{ha}$. The highest yield values $-2.87 \mathrm{t} /$ ha with $0.55 \mathrm{t} /$ ha increase over control was obtained at seeds treatment with Emistim $\mathrm{C}$ in combination with crop spraying with Reakom (4 1/ ha) in the budding-early flowering stages (Table 1).

The effect of biopreparation based on phosphorous mobilizing microorganisms on pea plants yield at seeds treatment was close to the action of nitrogen fixing bacteria. Hence, Ryzohumin inoculation had resulted in yield increase on $0.38 \mathrm{t} / \mathrm{ha}$, or $18.1 \%$, while seeds treatment with PMBC had ensured $-0.27 \mathrm{t} / \mathrm{ha}$, or $12.8 \%$. In control variant without inoculation the yield was $2.10 \mathrm{t} /$ ha.

The highest yield $-2.51 \mathrm{t} /$ ha in variants without presowing seeds bacterization was obtained at application of Reacom-C Beans (4 1/ t). Increase to control was $0.41 \mathrm{t} / \mathrm{ha}$, or $19.5 \%$. Use of Emistim $C$ for seed treatment had also resulted in high yield $-2.36 \mathrm{t} / \mathrm{ha}$, with the increase of $0.26 \mathrm{t} / \mathrm{ha}$. Higher yields of peas (3.02 and $3.03 \mathrm{t} / \mathrm{ha})$ were obtained at seeds inoculation with Ryzohumin combined with crops spraying with Emistim C (10 $\mathrm{mL} / \mathrm{ha}$ ) and in variant with seeds treated with Emistim $\mathrm{C}$ in combination with crops spraying with Reakom (4 $1 /$ ha ). Increase of yield to control $(2.10 \mathrm{t} / \mathrm{ha})$ was 0.92 and $0.93 \mathrm{t} / \mathrm{ha}$, while increase in comparison with the variants with inoculation $(2.48 \mathrm{t} / \mathrm{ha})-$ 0.54 and $0.55 \mathrm{t} / \mathrm{ha}$. Seeds treatment with PMBC was more effective in combination with 
Emistim C (10 mL / t) before sowing and crops spraying with Reakom (4 1/ ha). In this case increase to control was $1.08 \mathrm{t} / \mathrm{ha}$, while increase to the variants with plants inoculated with biopreparations $-0.81 \mathrm{t} / \mathrm{ha}$, or 51.4 and $34.2 \%$, respectively.

TABLE 1. Yield of pea (varietie Tsarevich) at complex use of biological preparations and microelements, t/ha (2009-2010)

\begin{tabular}{|c|c|c|c|c|c|}
\hline \multirow[b]{2}{*}{$\begin{array}{l}\text { Variants of micronutrients and } \\
\text { growth regulator application } \\
\text { (factor A) }\end{array}$} & \multicolumn{3}{|c|}{$\begin{array}{l}\text { Application of biopreparations } \\
\text { (factor B) }\end{array}$} & \multirow[b]{2}{*}{$\begin{array}{l}\text { Factor } \\
\text { A mean }\end{array}$} & \multirow{2}{*}{$\begin{array}{l}\text { Incre- } \\
\text { ase by } \\
\text { factor } \\
\text { A }\end{array}$} \\
\hline & $\begin{array}{l}\text { Without } \\
\text { bacteriza- } \\
\text { tion } \\
\text { (control) }\end{array}$ & $\begin{array}{l}\text { Rhizo- } \\
\text { humin }\end{array}$ & PMBC & & \\
\hline No treatment (control) & 2,10 & 2,48 & 2,37 & 2,32 & - \\
\hline $\begin{array}{l}\text { Reacom-C beans }(41 / \mathrm{g})-\text { seeds } \\
\text { treatment }\end{array}$ & 2,51 & 2,69 & 2,83 & 2,68 & $+0,36$ \\
\hline $\begin{array}{l}\text { Reacom-P beans ( } 4 \text { 1/ g) - crops } \\
\text { spraying }\end{array}$ & 2,45 & 2,62 & 2,96 & 2,68 & $+0,36$ \\
\hline $\begin{array}{l}\text { Emistim C }(10 \mathrm{ml} / \mathrm{ha})-\text { seeds } \\
\text { treatment }\end{array}$ & 2,36 & 2,70 & 2,98 & 2,73 & $+0,41$ \\
\hline $\begin{array}{l}\text { Emistim C (10 ml / ha }) \text { - crops } \\
\text { spraying }\end{array}$ & 2,31 & 3,02 & 2,80 & 2,71 & $+0,39$ \\
\hline $\begin{array}{l}\text { Reacom-C beans }(4 \mathrm{l} / \mathrm{g})+ \\
\text { Emistim C }(10 \mathrm{ml} / \mathrm{ha})-\text { seeds } \\
\text { treatment }\end{array}$ & 2,43 & 2,46 & 2,76 & 2,55 & $+0,23$ \\
\hline $\begin{array}{l}\text { Emistim C ( } 10 \mathrm{ml} / \mathrm{ha})- \text { seeds } \\
\text { treatment }+ \text { Reacom-P beans }(41 \\
/ \mathrm{g})- \text { crops spraying }\end{array}$ & 2,40 & 3,03 & 3,18 & 2,87 & $+0,55$ \\
\hline $\begin{array}{l}\text { Reacom-C beans }(41 / \mathrm{g})-\text { seeds } \\
\text { treatment }+ \text { Emistim C }(10 \mathrm{ml} / \\
\text { ha) - crops spraying }\end{array}$ & 2,31 & 2,68 & 2,64 & 2,54 & $+0,22$ \\
\hline $\begin{array}{l}\text { Reacom-P beans }(41 / \mathrm{g})+ \\
\text { Emistim C }(10 \mathrm{ml} / \mathrm{ha})-\text { crops } \\
\text { spraying }\end{array}$ & 2,42 & 2,84 & 2,71 & 2,66 & $+0,34$ \\
\hline Factor B mean & 2,36 & 2,72 & 2,80 & 2,64 & \\
\hline Increase by factor $\mathrm{B}$ & - & $+0,36$ & $+0,44$ & - & \\
\hline
\end{tabular}

$\mathrm{LCD}_{05}(\mathrm{~A})=0,12-0,13 \mathrm{~T} / \mathrm{\Gamma a}$;

$\mathrm{LCD}_{05}(\mathrm{~B})=0,07-0,08 \mathrm{\tau} / \mathrm{га}$;

$\mathrm{LCD}_{05}(\mathrm{AB})=0,20-0,22$ т/га

The protein content in pea seeds had changed under the influence of seeds inoculation with microbial agents, microelements and growth regulators. Thus, biological preparations on average had increased protein content in seeds on $0.8-1.1 \%$, Reacom on $0.8-1.3 \%$, Emistim C - on $1.3-1.7 \%$ (Table 2). 
TABLE 2. The protein content of pea seeds (variety Tsarevich) at complex use of biological preparations and microelements, \% (2009-2010)

\begin{tabular}{|c|c|c|c|c|c|}
\hline \multirow[b]{2}{*}{$\begin{array}{l}\text { Variants of micronutrients and } \\
\text { growth regulator application } \\
\text { (factor A) }\end{array}$} & \multicolumn{3}{|c|}{$\begin{array}{l}\text { Application of biopreparations } \\
\text { (factor B) }\end{array}$} & \multirow[b]{2}{*}{$\begin{array}{l}\text { Factor } \\
\text { A mean }\end{array}$} & \multirow{2}{*}{$\begin{array}{l}\text { Incre- } \\
\text { ase by } \\
\text { factor } \\
\text { A }\end{array}$} \\
\hline & $\begin{array}{l}\text { Without } \\
\text { bacteriza- } \\
\text { tion } \\
\text { (control) }\end{array}$ & $\begin{array}{l}\text { Rhizo- } \\
\text { humin }\end{array}$ & PMBC & & \\
\hline No treatment (control) & 18,8 & 19,9 & 19,5 & 19,4 & - \\
\hline $\begin{array}{l}\text { Reacom-C beans }(41 / \mathrm{g})-\text { seeds } \\
\text { treatment }\end{array}$ & 19,8 & 20,5 & 20,3 & 20,2 & $+0,8$ \\
\hline $\begin{array}{l}\text { Reacom-P beans }(41 / \mathrm{g}) \text { - crops } \\
\text { spraying }\end{array}$ & 20,1 & 21,2 & 20,8 & 20,7 & $+1,3$ \\
\hline $\begin{array}{l}\text { Emistim } \mathrm{C}(10 \mathrm{ml} / \mathrm{ha})-\text { seeds } \\
\text { treatment }\end{array}$ & 20,3 & 22,2 & 20,8 & 21,1 & $+1,7$ \\
\hline $\begin{array}{l}\text { Emistim C (10 ml / ha }) \text { - crops } \\
\text { spraying }\end{array}$ & 20,3 & 21,2 & 20,7 & 20,7 & $+1,3$ \\
\hline $\begin{array}{l}\text { Reacom-C beans }(41 / \mathrm{g})+ \\
\text { Emistim C }(10 \mathrm{ml} / \mathrm{ha})-\text { seeds } \\
\text { treatment }\end{array}$ & 19,0 & 20,2 & 20,3 & 19,8 & $+0,4$ \\
\hline $\begin{array}{l}\text { Emistim C }(10 \mathrm{ml} / \mathrm{ha})-\text { seeds } \\
\text { treatment }+ \text { Reacom-P beans }(41 \\
/ \mathrm{g}) \text { - crops spraying }\end{array}$ & 19,2 & 20,5 & 20,1 & 19,9 & $+0,5$ \\
\hline $\begin{array}{l}\text { Reacom-C beans }(41 / \mathrm{g})-\text { seeds } \\
\text { treatment }+ \text { Emistim C }(10 \mathrm{ml} / \\
\text { ha) - crops spraying }\end{array}$ & 19,9 & 20,5 & 20,7 & 20,4 & $+1,0$ \\
\hline $\begin{array}{l}\text { Reacom-P beans }(41 / \mathrm{g})+ \\
\text { Emistim } \mathrm{C}(10 \mathrm{ml} / \mathrm{ha})-\text { crops } \\
\text { spraying }\end{array}$ & 19,6 & 21,2 & 21,4 & 20,8 & $+1,4$ \\
\hline Factor B mean & 19,7 & 20,8 & 20,5 & 20,3 & \\
\hline Increase by factor B & - & $+1,1$ & $+0,8$ & & \\
\hline
\end{tabular}

High protein content in seeds was determined in variants with combined application of microfertilizer, growth regulator and Ryzohumin $-20.8 \%$. Presowing seeds treatment with PMBC had also improved protein content (20.5\%), whereas in control variants that value was on $19.7 \%$ level. Without seeds treatment with biological preparations the largest protein content in pea seeds $(20.3 \%)$ was determined in variant with Emistim C used for presowing seeds treatment and spraying of crops. Application of Ryzohumin had resulted in the largest protein content $(22.2 \%)$ in variants with seeds inoculation combined with growth regulator. For phosphorous mobilizing agent the highest value $(21.4 \%)$ was determined in variant with complex use of PMBC and crops spraying with growth regulator and micronutrient preparation. In comparison to control (without application of biological preparations) the increase was $1.5,3.4$ and $2.6 \%$, respectively. Seeds 
inoculation with Ryzohumin only had resulted in $1.1 \%$ protein content increase, PMBC $0.7 \%$ (19.9 and $19.5 \%$ values, respectively).

Estimation of economic efficiency for cultivation of pea plant of Tsarevich variety shows that without application of crop growth regulator, micronutrient fertilizer and biological preparations for pre-sowing seeds treatment (control) the production costs were $4257 \mathrm{UAH} / \mathrm{ha}$, with operating profit $-2358 \mathrm{UAH} /$ ha and profitability of production $55.4 \%$ (Table 3 ).

TABLE 3. The economic and energy efficiency of peas cultivation at complex use of biological preparations and microelements (2009-2010)

\begin{tabular}{|c|c|c|c|c|c|c|c|c|c|c|}
\hline $\begin{array}{l}\text { Seeds and } \\
\text { plants } \\
\text { treatment } \\
\text { with } \\
\text { microferti- } \\
\text { lizer and } \\
\text { PGR } \\
\text { (factor A) }\end{array}$ & $\begin{array}{l}\text { Use of } \\
\text { bacterial } \\
\text { preparati- } \\
\text { ons } \\
\text { (factor B) }\end{array}$ & 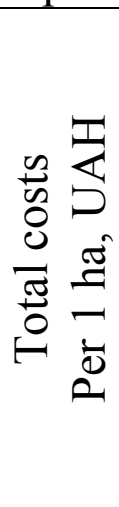 & 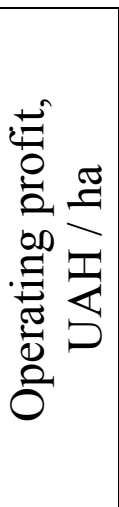 & $\begin{array}{l}00 \\
0 \\
0 \\
0 \\
0 \\
.0 \\
0 \\
0 \\
0 \\
0 \\
0 \\
0 \\
0 \\
0\end{array}$ & 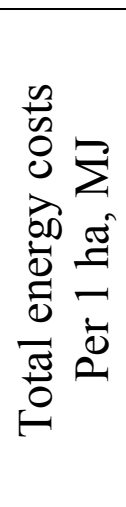 & 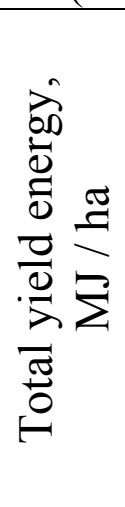 & 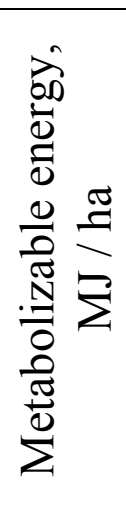 & 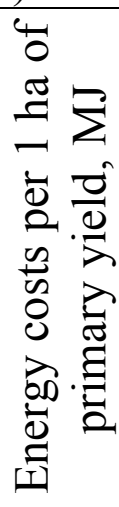 & 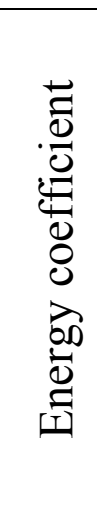 & 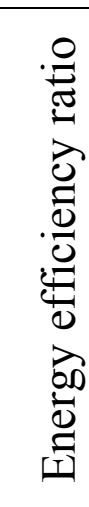 \\
\hline \multirow{3}{*}{$\begin{array}{l}\text { Without } \\
\text { treatment } \\
\text { (control) }\end{array}$} & bacterization & 4257 & 2358 & 55,4 & 18315 & 60994 & 35007 & 8721 & 3,33 & 1,91 \\
\hline & Rhizohumin & 4329 & 3483 & 80,5 & 8478 & 72054 & 41342 & 7451 & 3,90 & 2,24 \\
\hline & $\mathrm{PMI}$ & 4304 & 3161 & 73,4 & & 68837 & 39508 & 7769 & 3,74 & 2,14 \\
\hline \multirow{3}{*}{$\begin{array}{l}\text { Reakom-C- } \\
\text { beans } \\
(41 / t)\end{array}$} & $\begin{array}{l}\mathrm{W} / \mathrm{O} \\
\text { bacterization }\end{array}$ & 4348 & 3559 & 81,9 & 18380 & 72903 & 41842 & 7323 & 3,96 & 2,28 \\
\hline & Rhizohumin & 4411 & 4063 & 92,1 & 3543 & 78131 & 44842 & 6893 & 4,21 & 2,42 \\
\hline & PMBC & 4385 & 4530 & 103,3 & 8477 & 82163 & 47176 & 6529 & 4,45 & 2,55 \\
\hline \multirow{3}{*}{$\begin{array}{l}\text { Reakom-P- } \\
\text { beans } \\
\text { (4 1/ha) }\end{array}$} & $\begin{array}{l}\mathrm{W} / \mathrm{O} \\
\text { bacterization }\end{array}$ & 4431 & 3286 & 74,2 & 18602 & 71160 & 40841 & 7593 & 3,82 & 2,19 \\
\hline & Rhizohumin & 4494 & 3759 & 83,6 & 18765 & 76075 & 43675 & 7162 & 4,05 & 2,33 \\
\hline & $\mathrm{PMI}$ & 489 & 4835 & 107,7 & 18699 & 85973 & 49343 & 6317 & 4,60 & 2,64 \\
\hline \multirow{3}{*}{$\begin{array}{l}\text { Emistim C } \\
(10 \mathrm{ml} / \mathrm{t})\end{array}$} & $\begin{array}{l}\mathrm{W} / \mathrm{O} \\
\text { bacterization }\end{array}$ & 4287 & 3147 & 73,4 & 19632 & 68478 & 39341 & 8319 & 3,49 & 2,00 \\
\hline & Rhizohumin & 357 & 48 & 95,2 & 5 & 8421 & 09 & 7331 & 96 & 2,27 \\
\hline & PMBC & 337 & 5050 & 116,4 & 19729 & 6553 & 9676 & 6620 & 39 & 2,52 \\
\hline \multirow{3}{*}{$\begin{array}{l}\text { Emistim C } \\
(10 \mathrm{ml} / \mathrm{ha})\end{array}$} & $\begin{array}{l}\mathrm{W} / \mathrm{O} \\
\text { bacterization }\end{array}$ & 4284 & 2993 & 69,9 & 21965 & 67094 & 38508 & 9508 & 3,05 & 1,75 \\
\hline & Rhizohumin & 4370 & 5143 & 117,7 & 22128 & 87715 & 50343 & 7327 & 3,96 & 2,27 \\
\hline & PMBC & 4340 & 4480 & 103,2 & 22062 & 81326 & 46676 & 7879 & 3,68 & 2,11 \\
\hline \multirow{3}{*}{$\begin{array}{l}\text { Emistim C } \\
(10 \mathrm{ml} / \mathrm{t})+ \\
\text { Reakom-P- } \\
\text { beans } \\
(4 \mathrm{l} / \mathrm{ha})\end{array}$} & $\begin{array}{l}\mathrm{W} / \mathrm{O} \\
\text { bacterization }\end{array}$ & 4448 & 3112 & 70,0 & 19847 & 69708 & 40008 & 8269 & 3,51 & 2,01 \\
\hline & Rhizohumin & 4531 & 5014 & 110,7 & 20010 & 87972 & 50510 & 6604 & 4,40 & 2,52 \\
\hline & PMBC & 4505 & 5512 & 122,4 & 19944 & 92362 & 53010 & 6272 & 4,63 & 2,66 \\
\hline
\end{tabular}

At Combination of Emistim C (10 ml / m) and Reacom-P-beans (4 1/ ha) the additional operating profit of $945 \mathrm{UAH} /$ ha with recoupment of additional cost expenses 
4.95 UAH / ha, and the total income - $3112 \mathrm{UAH} /$ ha. Use of Ryzohumin in combination with crop spraying during budding - early flowering stage with Emistim $\mathrm{C}$ had resulted in operating profit of $5143 \mathrm{UAH} /$ ha and profitability $-117.7 \%$. Higher operating profit $5512 \mathrm{UAH} /$ ha and $122.4 \%$ cost-effectiveness was ensured by pre-sowing seeds treatment with PMBC and Emistim C (10 ml / m) followed by crops spraying with Reacom-P-beans (4 1/ ha).

Estimation of the energy efficiency for peas cultivation had showed that for $2.10 \mathrm{t} /$ ha yield in control, total energy consumption was $18315 \mathrm{MJ} /$ ha, while exchange one $35007 \mathrm{MJ} / \mathrm{ha}$, which corresponds to the energy efficiency growing ratio 1.91. Through the application of biologically active substances and bacterial preparations aggregate energy consumption increased on $97-3813 \mathrm{MJ} /$ ha. In addition to cost increase the growth of both total and metabolizable energy has been observed due to increase of primary and by-products yield. Thus, in the control variant the total energy output from harvest was $42679 \mathrm{MJ} /$ ha, while at application of Reacom-C-beans for pre-sowing seeds treatment it had raised to $54523 \mathrm{MJ} /$ ha and up to $52,558 \mathrm{MJ} /$ ha at crop spraying with Reacom-P-beans, with energy efficiency ratio 2.28 and 2.19, respectively. Use of Emistim $\mathrm{C}$ for seeds treatment and spraying of crops had accompanied by increase of total energy cost to $19632-21965 \mathrm{MJ} / \mathrm{ha}$, with metabolizable energy values equal to $38508-39341$ MJ / ha. At this energy efficiency ratio was 1.75 and 2.00, correspondingly. Seeds treatment with Ryzohumin and PMBC the total energy consumption had increased on 163 and $97 \mathrm{MJ} /$ ha while metabolizable energy - on 6305 and $4501 \mathrm{MJ} /$ ha. Energy efficiency ratio for Ryzohumin and $\mathrm{PMBC}$ was 2.24 and 2.14, respectively.

Combined use of Emistim $\mathrm{C}$ and Reacom-P-beans had increased metabolizable energy to $40008 \mathrm{MJ} /$ ha, while the total energy consumption was $19847 \mathrm{MJ} /$ ha. Gross energy accumulation at this was $49855 \mathrm{MJ} / \mathrm{ha}$, while the energy efficiency ratio -2.01 . Production of single ton of harvest requires 8721 , while in control variant this value was 8269 MJ. Additionally, pre-sowing seed inoculation with Ryzohumin had provided accumulation of metabolizable and total energy up to 50510 and $87972 \mathrm{MJ} / \mathrm{ha}$, correspondingly. Energy efficiency ratio in this case was 2.52. Seeds treatment with $\mathrm{PMBC}$ in combination with micronutrient fertilizer and growth regulator had increased accretion of gross energy to 92362 and metabolizable - to $53010 \mathrm{MJ} /$ ha, respectively, with EER equals to 2.66. Energy consumptions per single ton of primary products in variants with Rhizohumin were $6604 \mathrm{MJ}$ while in variants where PMBC was used - 6272 MJ.

Thus, use of Reacom fertilizer on peas (Tsarevich variety) has resulted in yield increase on $0.36 \mathrm{t} / \mathrm{ha}$, or $15.5 \%$, Emistim $\mathrm{C}-0.39-0.41 \mathrm{t} /$ ha or $16.8-17.7 \%$, and their combination - on $0.22-0.55 \mathrm{t} /$ ha or $9.5-23.7 \%$. Use of microbial preparations ensured yield increase - on $0.27-0.38 \mathrm{t} /$ ha or $12.8-18.1 \%$. Higher pea yields $(3.02$ and $3.03 \mathrm{t} /$ ha) were obtained in variants with pre-sowing seed inoculation with Rhizohumin and its combination with crop growth regulator Emistim $\mathrm{C}$ and Emistim $\mathrm{C}$ with Reakom solutions. Harvest increase in comparison to control was $0.92-0.93 \mathrm{t} / \mathrm{ha}$, correspondingly. Pre-sowing seed treatment with PMBC had a greater impact on peas yield in combination with Emistim C (10 ml/ m) and crops spraying with Reakom (4 1/ ha), which had increased the yield on $1.08 \mathrm{t} /$ ha. Application of microfertilizers solution had improved protein content in grain on $0.8-1.3 \%$, Emistim $\mathrm{C}-1.3-1.7 \%$, microbial 
preparations - on $0.8-1.1 \%$. The highest protein content $-22.2 \%$ was obtained in variants with Rhizohumin used for pre-sowing seeds treatment in combination with Emistim C. The highest net operating profit $5512 \mathrm{UAH} /$ ha and $122.4 \%$ return was obtained in the variants with pre-sowing seeds treatment with PMBC in combination with Emistim C (10 mL / t ) followed by crops spraying with Reacom-P-beans (4 1/ ha). Application of biologically active substances and microbial preparations in the technologies of pea cultivation had ensured accumulation of gross and metabolizable energy in crops and, correspondingly, increase of energy efficiency ratio. Higher rates of total energy accumulation - 92362 and metabolizable energy - 53010 , total energy gain $75418 \mathrm{MJ} /$ ha provided seed treatment PMBC and Emistim C $(10 \mathrm{ml} / \mathrm{m})$ combined with spraying of crops with Reacom-P-beans (4 1/ ha). Energy consumption per single ton of primary products were $6272 \mathrm{MJ}$ and EER was 2.66. In control variants those values were $8721 \mathrm{MJ} / \mathrm{t}$ and 1.91, respectively. 